\title{
Institutional Efficiency, Monitoring Costs, and the Investment Share of FDI
}

\author{
Joshua Aizenman and Mark M. Spiegel*
}

\begin{abstract}
This paper models and tests the implications of institutional efficiency on the pattern of foreign direct investment (FDI). We posit that domestic agents have a comparative advantage over foreign agents in overcoming some of the obstacles associated with corruption and weak institutions. We model these circumstances in a principal-agent framework with costly ex-post monitoring and enforcement of an ex-ante labor contract. Expost monitoring and enforcement costs are assumed to be lower for domestic entrepreneurs than for foreign ones, but foreign producers enjoy a countervailing productivity advantage. Under these asymmetries, multinationals pay higher wages than domestic producers, in line with the insight of efficiency wages and with the evidence about the 'multinationals wage premium.' FDI is also more sensitive to increases in enforcement costs.

We then test this prediction for a cross section of developing countries. We use Mauro's (1995) index of institutional efficiency as an indicator of the strength of property rights enforcement within a given country. We compare institutional efficiency levels for a large cross section of countries in 1989 to subsequent FDI flows from 1990 to 1999 . We find that institutional efficiency is positively associated with the ratio of subsequent foreign direct investment flows to both gross fixed capital formation and to private investment. This finding is true for both simple cross-sections and for cross-sections weighted by country size.
\end{abstract}

Keywords: Multinational corporations, corruption, property rights, wage premium

JEL classification: F21, F23, J31, P14

Joshua Aizenman (correspondence)

Department of Economics, UCSC, 217 Social Sciences 1

Santa Cruz, CA USA 95064

Tel: (831) 459-4791

Fax: (831) 459-5900

Email jaizen@cats.ucsc.edu

\author{
Mark M. Spiegel \\ Federal Reserve Bank of San Francisco \\ 101 Market St. \\ San Francisco CA 94105 \\ Tel: (415) 974-3241 \\ Fax: (415) 974-2168 \\ Email mark.spiegel@sf.sf.frb.org
}

\footnotetext{
${ }^{*}$ Edmund Chiang provided excellent research assistance. Helpful comments were received from seminar participants at U.C. Santa Cruz and the Federal Reserve Bank of San Francisco. The views expressed in this paper represent those of the authors alone and do not necessarily reflect the views of the Federal Reserve Board, the Federal Reserve Bank of San Francisco, or the National Bureau of Economic Research.
} 


\section{Introduction}

The large increase in FDI in recent decades has stimulated a growing empirical and theoretical literature. ${ }^{1}$ The salient empirical regularities emerging from this literature include the finding of a hefty "multinational wage premium" - multinationals' wages exceed the wages paid by domestic producers by a significant margin, and multinationals' productivity tends to be higher than that of domestic producers. ${ }^{2}$ The purpose of this paper is to outline and to test a model that provides an interpretation to these findings. Specifically, we identify situations where it is in multinational's self interest to pay a wage premium relative to domestic producers.

A number of previous papers have concentrated on knowledge spillovers as an argument for a multinational wage premium. Fosfuri, et al (2001) introduce a model where a multinational pays its trained workers a higher wage to induce it to resist moving to a local competitor.

Our analysis focuses instead on the role of strength in the enforcement of property rights, as measured by the domestic level of institutional efficiency, on the pattern and behavior of multinationals. Despite efforts to limit such behavior, corruption and bribery appear to be prevalent features of foreign direct investment activities. For example, Hines (1995) examines the impact of the Foreign Corrupt Practices Act of 1977 forbidding foreign bribery by American firms on subsequent FDI growth in corrupt nations originating in the United States. Hines finds that the law put US firms at a competitive disadvantage in those states as growth in FDI originating in the US in corrupt states was significantly lower than in non-corrupt states subsequent to the law's passage. A number of studies [e.g. Markusen (2001), Wei (1997a, b), and Smarzynska and Wei (2000)], have posited that institutional inefficiencies such as corruption will be detrimental to both FDI and domestic investment.

The empirical evidence concerning the impact of institutional efficiency and property rights enforcement on inward investment has been mixed. Wheeler and Mody (1992) estimate a cross-country panel of manufacturing and electronics investment in which a principal component they label "Risk" includes such socio-economic factors as the Business International indicators of corruption and bureaucratic red tape. They find no significant

\footnotetext{
${ }^{1}$ See Markusen (2002) and Feenstra (2002, Chapter 11) for overview of multinationals, and Lipsey (2002) for a review of the empirical evidence.

${ }^{2}$ See Blomström (1983b), Haddad and Harrison (1993), Okamoto and Sjöholm (1999), Lipsey and Sjöholm (2001) and the references in Lipsey (2002).
} 
impact of this component on capital expenditures by U.S. multinationals. Similarly, Hines (1995) finds no measurable impact of corruption on total inward FDI in host nations after 1977.

However, more recent studies find robust evidence that corruption reduces the level of FDI entering into a country. Wei (2000) examines a panel of bilateral stocks of FDI from 12 source countries to 45 host countries and finds a large and statistically significant negative impact of corruption on inward FDI. His point estimates indicate that the increase in corruption from the level of Singapore's to that of Mexico is the equivalent of a 20 percentage point increase in the tax rate on multinationals. Similarly, Wei (1997) finds that uncertainty in corruption levels also has a measurable negative impact on inward FDI.

While these later studies establish a negative relationship between corruption and FDI, their results do not imply that FDI flows would be more sensitive to host country corruption levels than domestic investment. Domestic investment rates are also likely to respond negatively to corruption levels. However, the possibility that corruption is especially harmful to FDI, i.e. relative to its adverse impact on domestic investment, is important in terms of the general consensus that FDI plays an important role in transferring technology to developing countries. ${ }^{3}$

We conjecture that FDI will be more sensitive to institutional inefficiencies than domestic investment. We posit that domestic entrepreneurs will have an advantage in overcoming institutional inefficiencies relative to their foreign competitors in overcoming some of the obstacles associated with corruption and weak institutions. This may be due to multitude of reasons, including better familiarity of the court system and the government, better knowledge of the key people that should be bribed and of local networks that help in resolving disputes, etc. Our model focuses on the implications of this presumption on the employment and investment patterns of domestic versus foreign entrepreneurs. ${ }^{4}$

Specifically, we model such circumstances in a principle agent framework with costly ex-post monitoring and enforcement of an ex-ante contract with domestic labor. The home advantage stems from our assumption that the ex-post monitoring and

\footnotetext{
${ }^{3}$ For example, see Barrel and Pain (1997). However, see Aitken and Harrison (1999) for an opposing view.

${ }^{4}$ The literature has dealt with other possible dimensions associated with home advantages and disadvantages of domestic versus foreign entrepreneurs. For example, Razin, Sadka and Yuen (1999) studied the implication of multinationals having access to cheaper cost credit and possibly inferior information about the quality of domestic projects relative to domestic entrepreneurs on the patterns of FDI. Our approach abstracts away from these issues, assuming equal financial costs for both domestic and foreign agents. This allows us to identify the implications of the home advantage associated with contract enforcement on the patterns of investment. An implication of our assumptions is that, unlike in Razin et. al. (1999), FDI unambiguously improves the host county's welfare.
} 
enforcement cost of the labor contract is lower for domestic entrepreneurs than for foreign ones. Under these disadvantages, foreign producers require a countervailing productivity advantage to compete. Given circumstances where both multinationals and domestic producers exist side-by-side, we show that multinationals pay higher wages than domestic producers, in line with the insight of efficiency wages and with the evidence about the 'multinationals wage premium.' We also show that multinational investments are more sensitive to weakness (or more costly enforcement of) property rights.

We then directly examine the impact of institutional efficiency on the share of FDI in a host country's overall investment portfolio. In particular, we estimate the impact of an index of institutional efficiency on the ratio of average FDI flows to both gross fixed capital formation and private domestic investment over the following ten years for a cross-section of nations. We find that institutional efficiency is robustly positively correlated with the ratio of FDI to total domestic investment. This suggests that institutional inefficiency discourages FDI more severely than it does domestic investment, as predicted by our theoretical model. We then demonstrate that this result is robust to the inclusion of a number of conditioning factors.

This paper is organized into five sections. Section 2 introduces a simple principalagent model of foreign direct investment with imperfect property rights protection. Section 3 discusses the empirical methodology and data used in the paper. Section 4 reviews our results and conducts some robustness testing. Section 5 concludes.

\section{A Simple Model of FDI with Imperfect Property Right Enforcement}

In this section, we introduce a simple model of FDI with imperfect property right enforcement. We assume that there is a sector containing two firms, a multinational subsidiary and a domestic firm. Both of these firms are assumed to face a principal-agent problem vis-à-vis their laborers, with costly ex-post monitoring and enforcement of an exante contract. FDI is assumed to co-exist with domestic production, where the technological superiority of foreign subsidiaries and the relative superiority of domestic firms concerning the agency problem lead to an interior solution for the share of FDI in host-country investment.

The production functions of the domestic and foreign firms are assumed to be CobbDouglas in capital, $K$, and labor, $L$. We distinguish the foreign firm with stars. The production function of the domestic firm is assumed to satisfy 


$$
Y=z A K^{\alpha} L^{\beta}
$$

where $z$ is the effective productivity shock, the outcome of labor's effort and the realized exogenous state of nature, $\varepsilon$ :

$$
z=\left\{\begin{array}{l}
1+\varepsilon \text { with } L \text { effort } \\
\chi(1+\varepsilon) \text { no } L \text { effort }
\end{array}\right.
$$

Labor's effort therefore contributes $1-\chi$ to output.

Similarly, the foreign firm production function is assumed to satisfy

$$
Y^{*}=z^{*} A^{*} K^{* \alpha} L^{* \beta}
$$

where $z^{*}$ satisfies

$$
z^{*}=\left\{\begin{array}{l}
1+\varepsilon^{*} \text { with } L \text { effort } \\
\chi\left(1+\varepsilon^{*}\right) \text { no } L \text { effort }
\end{array}\right.
$$

We assume that $\varepsilon$ and $\varepsilon^{*}$ are independently distributed uniform on the interval $[-\bar{\varepsilon}, \bar{\varepsilon}]$

We start the analysis with the simplest benchmark by ignoring the possibility of random monitoring and random shirking. In the absence of spending monitoring and verification costs, the representative entrepreneur in the domestic and foreign sector observes only the effective productivity shocks, $z$ and $z^{*}$ respectively. Verification of labor effort can be done only ex-post, after the realization of output. The cost of verifying labor's effort is assumed to equal proportions $c$ and $c^{*}$ of the labor inputs, $c L$ and $c^{*} L^{*}$ respectively. Since the cost is likely to be highly correlated within a country, we assume that $c^{*}=\psi c$. Moreover, we assume that the domestic firm enjoys a low cost of verifying and enforcing effort, such that $\psi>1$. However, we assume that the foreign subsidiary enjoys a countervailing productivity advantage over its domestic counterpart, so that $A^{*} \geq A$.

The opportunity cost of labor's time is assumed to equal $\omega .^{5}$ There are two possible labor types, differing in the amount of effort $e$ needed to yield the high output [alternatively, two possible qualities of matches between labor and capital, differing in the effort input needed]:

\footnotetext{
${ }^{5}$ The opportunity cost of labor could be alternatively interpreted as leisure or as the prevailing wage in a traditional sector.
} 


$$
e=\left\{\begin{array}{l}
e_{a} \text { with probability } a \\
e_{b} \text { with probability } b
\end{array}\right.
$$

where $e_{a}<e_{b}$ and $a+b=1$.

Labor's utility satisfies

$$
U=C-[\omega+e] L
$$

where $C$ is labor consumption and $\omega \geq 0$ is the shadow price of leisure. With perfect information, labor is paid the sum of $\left(\omega+e_{i}\right) L(i=a, b)$ with effort, and $\omega L$ with no effort. Labor knows its type, and its effort decision is endogenous. The entrepreneurs observe only the effective productivity shock $[(1+\varepsilon) \chi$ or $1+\varepsilon$, depending on labor's effort]. Ex-post, the entrepreneur may decide to pay the verification and enforcement cost in order to reveal labor's effort. In the absence of verification and enforcement, labor's compensation is not contingent on effort.

The labor contract sets the compensation rule ex-ante. It has the following dimensions

- A threshold $\phi$ of the effective productivity shock $z$ that will trigger the costly verification and enforcement.

- In the absence of verification, or if the verification will reveal no shirking, labor would be paid $w_{n} L$. If shirking is detected, labor would be paid zero. ${ }^{6}$

We assume that the various parameters induce a separating equilibrium, where the more efficient type (a) would supply effort, and the less efficient type $(b)$ would shirk.

In rational-expectation equilibrium, labor would prefer putting effort to shirking if the penalty for shirking exceeds the cost of effort. Under the assumptions above, this condition satisfies

$$
\frac{\phi+\bar{\varepsilon}}{2 \bar{\varepsilon}} w_{n}>e_{i}
$$

and

$$
w_{n} \geq \omega+e_{i}
$$

Henceforth, we assume that

$$
\omega+e_{b}>w_{n} \geq \frac{2 \bar{\varepsilon} e_{a}}{\phi+\bar{\varepsilon}} \geq \omega+e_{a}
$$

\footnotetext{
${ }^{6}$ Maximizing the penalty associated with shirking (i.e., paying zero when shirking is detected), is optimal.
} 
This implies that the density function of effective productivity shock $z$ is

$$
f(z)=\left\{\begin{array}{l}
\frac{b}{2 \bar{\varepsilon} \chi} \text { for }(1-\bar{\varepsilon}) \chi<z<1-\bar{\varepsilon} \\
\frac{b}{2 \bar{\varepsilon} \chi}+\frac{a}{2 \bar{\varepsilon}} \text { for } 1-\bar{\varepsilon}<z<(1+\bar{\varepsilon}) \chi \\
\frac{a}{2 \bar{\varepsilon}} \text { for }(1+\bar{\varepsilon}) \chi<z<1+\bar{\varepsilon}
\end{array}\right.
$$

The decision problems faced by the domestic and foreign entrepreneurs are identical. The domestic entrepreneur sets the contract in order to maximize the expected profits $V$, where

$$
V=[1-(1-\chi) b] A K^{\alpha} L^{\beta}-(1+\rho) K-L E(l c)
$$

where the cost of capital is equal to $1+\rho$ and $E(l c)$ represents the expected cost per worker, which satisfies

$$
E(l c)=w_{n}\left[1-\int_{(1-\bar{\varepsilon}) \chi}^{\phi} \frac{b}{2 \bar{\varepsilon} \chi} d z\right]+c \int_{(1-\bar{\varepsilon}) \chi}^{\phi} f(z) \frac{1}{2 \bar{\varepsilon}} d z
$$

The first term on the RHS of equation (1.11) represents expected output. The second term is the cost of capital; the third is the expected cost of labor. The cost of employing a worker, $E(l c)$, takes into account that the wage payment to shirking labor will be zero when the worker shirks, and that employing labor is associated with the expected cost of monitoring and enforcement [the second term of $E(l c)]^{7}$

Henceforth we focus on the case where the entrepreneur pays labor the reservation wage that just induces laborers of type $a$ to supply effort:

$$
w_{n}=\frac{2 \bar{\varepsilon} e_{a}}{\phi+\bar{\varepsilon}}
$$

\footnotetext{
${ }^{7}$ Note that the support on the second term begins at $(1-\bar{\varepsilon}) \chi$. For analytic simplicity, we combine the labor monitoring and enforcement costs together. However, in the range $(1-\bar{\varepsilon}) \chi \leq z \leq(1-\bar{\varepsilon})$, the entrepreneur would optimally choose only to pay the enforcement costs and not monitor, since monitoring is not needed to establish that a worker is of type $\mathrm{b}$ in that range. Similarly, within the range $(1-\bar{\varepsilon}) \leq z \leq \phi$, the entrepreneur would always need to monitor to establish labor's type, but would only face enforcement costs when the laborer turned out to be of type b. While this is clearly a simplification, it drives none of the qualitative results. We return to this simplification in the conclusion.
} 
Optimizing V with respect to $\phi, K$, and $L$, we infer:

CLAIM 1: An internal separating equilibrium (i.e., where type b would shirk, and type a would supply the needed effort) is characterized by

$$
\frac{d L}{d c}<0 ; \frac{d K}{d c}<0 ; \frac{d \phi}{d c}<0 ; \frac{d w_{n}}{d c}>0
$$

and

CLAIM 2: The capital labor ratio and the optimal investment levels depend negatively on the expected cost of labor, E(lc).

Proof: see the appendix. ${ }^{8}$

Our results follow the logic of efficiency wages. Higher monitoring costs would induce lower incidence of monitoring and enforcement, leading the entrepreneur to pay higher wages. The net outcome is higher wage, needed to keep the penalty associated with shirking high enough despite the drop in the incidence of monitoring. A by-product of it is that investment and employment will drop.

Finally, the level of monitoring and enforcement costs will affect the relative levels of domestic and foreign investment, as noted in the following claim:

CLAIM 3: Higher enforcement costs (maintaining constant the relative cost disadvantage of the foreign producer, $\psi$ ) reduce the ratio of multinational investment to domestic investment at a rate that increases with the enforcement cost gap.

Proof:

Denoting the optimal stock of capital in the domestic firm by $\widetilde{K}$, and the probability of enforcing and monitoring in the domestic industry by Q, we demonstrate in the appendix that

$$
d\left\{\frac{c Q}{E[l c]}\right\} / d c>0
$$

\footnotetext{
8 The comparative static are simplified considerably by the observation that around the optimum $V_{K, \phi}^{\prime \prime}=V_{L, \phi}^{\prime \prime}=V_{K, c}^{\prime \prime}=0$.
} 
and

$$
\frac{d \log [\tilde{K} * / \tilde{K}]}{d c}=\frac{\beta}{1-\alpha-\beta} \frac{1}{c}\left\{\frac{c Q}{E[l c]}-\frac{c^{*} Q^{*}}{E\left[l c^{*}\right]}\right\}<0
$$

as predicted in Claim 3.

The intuition behind Claim 3 is that higher enforcement costs increase the ratio of expected enforcement costs to total worker cost, which is $c Q / E(l c)$ for the domestic firm and $c^{*} Q^{*} / E\left(l c^{*}\right)$ for the foreign firm. ${ }^{9}$ The decrease in the ratio of foreign to domestic investment resulting from an increase in enforcement costs will then be proportional to the difference in the monitoring and enforcement cost ratios of domestic and foreign producers. The observation that the enforcement cost ratio increases with the level of enforcement cost implies that the greater is the cost gap, the larger is the drop of the relative capital share induced by a given increase in the monitoring and enforcement costs, c.

Our model therefore predicts that multinationals characterized with higher productivity and higher cost of monitoring and enforcement will opt to pay higher wages. Moreover, the greater is the cost of domestic enforcement $c$, the lower will be the ratio of foreign direct investment to domestic investment. In the following section, we test the latter empirical prediction.

\section{Empirics}

\subsection{Methodology}

The theoretical model above implied that foreign direct investment would constitute a smaller share of the overall investment package in countries that had inferior property rights protection. In this section, we test this theory empirically for a cross-section of countries using data on institutional efficiency.

We first estimate the following specification

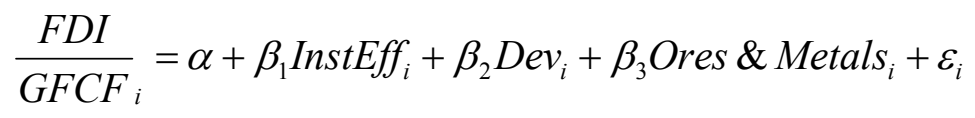

where $F D I / G C F C_{i}$ represents the average ratio of inward foreign direct investment to gross

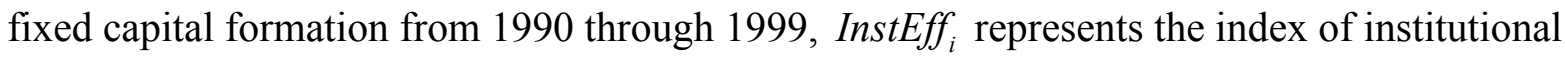
efficiency from Mauro (1995), discussed in more detail below, $D e v_{i}$ represents a zero-one

\footnotetext{
${ }^{9}$ The higher cost $\mathrm{c}$ induces a relatively small drop in the probability of monitoring and
} 
dummy indicating a developed country, Ores \& Metals $_{i}$ represents the share of exports comprised of ores and metals, and $\varepsilon_{i}$ represents a disturbance term that is assumed to be independently and identically distributed normal.

We estimate equation (1.16) with and without the Ores \& Metals $s_{i}$ variable, which is introduced to identify countries that are intensive in activities traditionally associated with high levels of foreign direct investment. ${ }^{10}$ We also estimate equation (1.16) with and without weighting our observations by country size, as measured by gross domestic product in 1989 . Finally, we report our results with developed and developing countries pooled with the $D e v_{i}$ dummy included as well as the two samples separated.

Our coefficient of interest is $\beta_{1}$, the impact of the institutional efficiency index in 1989 on subsequent inward foreign direct investment as a share of gross fixed capital formation. The model is estimated using ordinary least squares with White's heteroscedasticity-consistent standard errors below.

Since heterogeneity in government investment may add noise to the denominator in the dependent variable in our specification above, we repeat our estimation using the ratio of average inward foreign direct investment to private domestic investment, $F D I / P V T_{i}$, from 1990-1999. This specification results in a smaller sample, but provides a good check of the robustness of the results we report for the larger sample.

\subsection{Data}

Institutional efficiency data was obtained from Mauro (1995). The data are from Business International's index of institutional efficiency, and reflect the reports of analysts concerning the functioning of the domestic bureaucracy, with a grade of 10 indicating a "smoothly functioning, efficient bureaucracy" while a grade of 4 indicates "constant need for government approvals and frequent delays."

Remaining data, including foreign direct investment flows, gross fixed capital formation, the share of private investment in total domestic investment, and the shares of ores and metals in total exports, were obtained from the World Development Indicators.

enforcement, $Q$, such that the net effect is increasing $\frac{c Q}{E[l c]}$.

${ }^{10}$ The oil industry is also commonly associated with high shares of foreign direct investment. Using the set of oil-exporting countries identified in Mankiw, Romer and Weil (1992), two of the countries in our data set, Gabon and Iran, can be considered oil-exporting. We re-ran the regressions with these two countries omitted and obtained very similar results. These are available upon request. 
Countries were designated as "developed" on the basis of membership in the OECD in November 1988.

Summary statistics are shown in Table 1. Our sample includes 97 countries, 76 of which are designated as developing and 21 of which are designated as developed. It can be seen that the inclusion of the Ores \& Metals variable reduces our sample size to 71, while using the $F D I / P V T_{i}$ dependent variable instead of $F D I / G C F C_{i}$ reduces the sample size to 52 countries, only 10 of which are developed. Consequently, we do not report results for the developed countries alone with this dependent variable.

Unsurprisingly, the developing nations score poorly relative to the developed nations in the InstEff $i$ index, with the developing nations' mean index at 4.67 while the developed nations' index has a mean of 8.874. Nevertheless there is a fair amount of disparity within both samples, with the developing nations ranging from 0 to 8.33 while the developed nations range from 6.67 to 10 .

One might expect that the developing nations would have a higher share of inward foreign direct investment. However, the data show that that is not necessarily the case. In fact, the mean ratio of foreign direct investment to gross fixed capital formation is slightly larger for the developed nations. In contrast, the mean ratio of FDI to private domestic investment is larger for the developing nations, as we might expect. Nevertheless, neither difference is statistically significant.

The simple correlations between our InstEff $f_{i}$ index and levels of investment relative to gross domestic product for our developing nation sample are shown in Figure 1. It can be seen that there is a modest positive raw relationship between property rights protection and both FDI and domestic investment as measured by gross fixed capital formation. This confirms the results found in Wei (2000). ${ }^{11}$ We plot the simple correlation between the InstEff $_{i}$ index and the $F D I / G C F C_{i}$ and $F D I / P V T_{i}$ ratios in Figure 2 for our developing country sample. We observe a modest positive relationship between protection of property rights protection and these ratios, as predicted by our theory. We next turn towards testing these hypotheses formally. ${ }^{12}$

\footnotetext{
${ }^{11}$ The full sample also displayed a modest positive relationship. However, as developed countries tend to have much lower corruption scores, we include a dummy to identify the developed nations in our parametric analysis with the full sample below.

${ }^{12}$ Figures 1 and 2 reveal that there is a lot of clustering in the institutional efficiency ratings. In response, we also ran the regressions below with estimators robust to clustering and obtained essentially identical results, These are available from the authors on request.
} 


\section{Results}

\subsection{Base Specification}

Results with $F D I / G C F C_{i}$ as the dependent variable are shown in Table 2. It can be seen that the performance of the $\operatorname{InstEff}_{i}$ variable is very robust. With the sample weighted by country size, the variable enters positively and significantly either with or without controlling for the share of ores and metals exports. The point estimate of slightly over 0.02 implies an economically significant 2 percent increase in the ratio of FDI to gross fixed capital formation for each point increase in the corruption index.

With the unweighted sample, the variable enters positively and significantly after controlling for ores and metals exports, but is insignificant without this control. However, we focus primarily on the weighted results to avoid results dominated by small outliers. The very small R-squared results we obtain in all of the unweighted regressions reported suggest that the weighted samples contain far less noise.

The control variables enter as would be expected. The $D e v_{i}$ variable is negative and statistically significant for the weighted samples. The Ores \& Metals $s_{i}$ variable enters positively and significantly at least a ten percent confidence level with either the weighted or un-weighted specifications.

We then break the sample up into its developed and developing nation sub-samples and obtain similar results. For both sub-samples, the $\operatorname{InstEff}_{i}$ variable enters positively and significantly for both specifications with a weighted sample, and after controlling for ores and metal exports with the un-weighted sample. There is a notable difference in the point estimates between the two sub-samples, although this difference is not statistically significant.

Table 3 displays the results with $F D I / P V T_{i}$ as the dependent variable. As noted above, the use of this variable significantly reduces our sample size. Indeed, the data is available for this reduced sample for only ten of the developed nations, so we do not report regression results for that sub-sample with this dependent variable. ${ }^{13}$ Nevertheless, our results for the $\operatorname{InstEff}_{i}$ variable of interest appear to be robust in the full sample. As was the case for the ratio to gross fixed capital formation, the $\operatorname{InstEff}_{i}$ variable enters positively and

\footnotetext{
${ }^{13}$ For completeness, we did run the specification with this sub-sample. Unsurprisingly, everything was very insignificant, including all of the control variables.
} 
significantly in both of the specifications with the weighted sample and with the un-weighted sample after controlling for the share of ores and metals exports. The coefficient values are also quite similar to those we obtained in the gross fixed capital formation regressions.

The results with the developed country sample alone are also similar. The InstEff variable enters significantly in the weighted specification without controlling for ores and metals, and is close to a 10 percent confidence level with the control included. As above, the InstEff $_{i}$ variable also enters significantly with its expected positive coefficient with the Ores \& Metals $_{i}$ control included.

\subsection{Robustness to Inclusion of Conditioning Variables}

Because we are estimating a cross-section, we obviously are precluded from using panel estimators, such as country fixed and random effects, to control for differences in country characteristics outside of our theory that may independently influence the relative share of FDI in investment. To account for other possible influences, we introduce a number of conditioning variables into our specification from the Sachs and Warner (1997) data set. ${ }^{14}$

The conditioning variables introduced are Sub-Sahara, a dummy indicating SubSaharan African nations, Openness, an indicator of the degree to which domestic policy favors free trade, Access, a dummy indicating a nation having navigable access to the sea, Tropics, a variable measuring the share of land area subject to a tropical climate, Life, the log of life expectancy at birth measured between 1965 and 1970, and a measure of Ethnolinguistic fractionalization. The latter variable measures the probability that two randomlyselected people from a country will not belong to the same ethnic or linguistic group.

Our results for the impact of corruption on the ratio of FDI to gross fixed capital formation is shown in Table 4. All specifications are weighted by country size. As before, we estimate the full sample with a dummy variable to indicate developed nations.

The first column introduces all of the conditioning variables simultaneously. It can be seen that the Corruption variable is insignificant after conditioning for the shares of ores and metal exports, but is significant at a ten percent confidence level with this conditioning variable.

Some exploration revealed that the Ethno-linguistic fractionalization variable displayed a high influence, and therefore the second column repeats the specification with

\footnotetext{
${ }^{14}$ See Sachs and Warner (1997) for original data sources.
} 
this variable dropped. The Corruption variable is now positive and significant at a five percent level as before with or without conditioning for ores and metals export shares. ${ }^{15}$

Finally, we introduce the conditioning variables one at a time. It can be seen that the significance of the Corruption variable is robust to the inclusion of any of the conditioning variables individually, either with or without conditioning for the ores and metals share. Moreover, the point estimate for the variable coefficient is similar to that of the weighted fullsample regression above. On their own, the conditioning variables do not appear to be significant, with the exception of the influential Ethno-linguistic fractionalization variable discussed earlier.

Table 5 repeats all of the specifications for FDI as a share of private investment. The results are quite similar to those in Table 4. With the exception of the inclusion of all of the conditioning variables, the Corruption variable is robustly positive. As before, if we exclude the Ethno-linguistic fractionalization variable, the Corruption variable enters positively and significantly (column 2).

In summary, the Corruption term appears to be strongly robust to the inclusion of the conditioning variables, either for FDI as a share of gross-fixed-capital formation or for FDI as a share of private investment. The only exception was the specification that included all of the conditioning variables. When the Ethno-linguistic fractionalization variable was excluded, the Corruption variable always entered positively and significantly, as predicted. ${ }^{16}$

\footnotetext{
${ }^{15}$ We also found that the Life variable was influential. Its exclusion resulted in the Corruption variable entering significantly even with the Ethno-linguistic fractionalization variable retained for FDI as a share of gross-fixed capital formation.

${ }^{16}$ The high influence of the ethno-linguistic fractionalization variable is puzzling. The correlation coefficient between it and the Corruption variable is only -0.28 . Moreover, the introduction of the variable only results in the exclusion of one observation from the sample, China. However, excluding China while also excluding the ethno-linguistic fractionalization variable also results in the Corruption variable entering significantly positive.
} 


\section{Conclusion}

This paper introduced a model of foreign direct investment with costly enforcement of property rights. We demonstrated that when foreign direct investment suffered from a relative disadvantage in property rights protection, it economized on its physical capital investment and paid its laborers a higher wage premium. This premium induced a separating equilibrium where the relatively productive workers refrained from shirking, while the less productive workers shirked. Finally, we demonstrated that the ratio of multinational investment to domestic investment would be increasing in the security of property rights.

We then tested this prediction for a cross-section of countries using data on corruption. Our results demonstrated a robust negative relationship between the level of corruption and the ratio of FDI flows to domestic investment flows.

It should be noted that a number of our simplifying assumptions above do not drive our results. For example, our assumption of a uniform distribution for the productivity shock resulted in a widening of the tails of the distribution, where monitoring is not required to identify the worker's type. Using a more standard distribution, such as a normal, the probability space where monitoring was required would be likely to increase, and thereby increase the property rights advantage of the domestic firm in a corrupt environment.

Another simplification noted earlier was the implicit combination of monitoring and enforcement activities. While the domestic entrepreneur is likely to enjoy advantages in both of these activities, as specified above, one could imagine a situation where relative advantages in monitoring may differ by industry. Holding enforcement costs equal, we may see multinational investment relatively specialized in industries in which foreign firms enjoy relative advantages in monitoring costs. For example, multinationals may enjoy managerial advantages in some industries, which may correspond to reduced monitoring costs, but may suffer from the enforcement disadvantages alluded to above.

Finally, the wage premium result above came from the specification of property rights limitations concerning the enforcement of labor effort. However, one could easily imagine a scenario where the employment of capital also resulted in enforcement problems. In future work, we will also allow for property right limitations to arise in this dimension. 


\section{Appendix}

This Appendix summarizes the derivation of the claims discussed in the paper.

\section{Proof of Claims 1 and 2}

The first order conditions corresponding to the entrepreneur's problem are:

$$
\frac{d V}{d L}=\beta \frac{E(Y)}{L} E(l c)=0
$$

$$
\begin{gathered}
\frac{\partial V}{\partial K}=\alpha \frac{E(Y)}{K}-(1+\rho)=0 \\
\frac{\partial V}{\partial \phi}=-L \frac{\partial E(l c)}{\partial \phi}=0
\end{gathered}
$$

Note that around the equilibrium

$$
V_{L, \phi}^{\prime \prime}=-\frac{\partial E(l c)}{\partial \phi}=0,
$$

where the last equality follows from the first order condition (A1) determining the threshold in order to minimize the expected cost of employing a worker. In addition, note that

$$
V_{K, c}^{\prime \prime}=V_{K, \phi}^{\prime \prime}=V_{\phi, L}^{\prime \prime}=V_{\phi, K}^{\prime \prime}=0 .
$$

It is easy to confirm that

$$
V_{\phi, \phi}^{\prime \prime}<0 ; \quad V_{\phi, c}^{\prime \prime}<0 ; \quad V_{L, c}^{\prime \prime}<0 .
$$

The comparative static of the system are determined by

$$
\left[\begin{array}{ccc}
V_{K, K}^{\prime \prime} & V_{K, L}^{\prime \prime} & 0 \\
V_{L, K}^{\prime \prime} & V_{L, L}^{\prime \prime} & 0 \\
0 & 0 & V_{\phi, \phi}^{\prime \prime}
\end{array}\right]\left[\begin{array}{l}
d K / d c \\
d L / d c \\
d \phi / d c
\end{array}\right]=-\left[\begin{array}{c}
0 \\
V_{L, c}^{\prime \prime} \\
V_{\phi, c}^{\prime \prime}
\end{array}\right] .
$$

It is easy to confirm that the second order conditions for maximization hold, and the determinate of the system is negative. 
Hence,

$$
\operatorname{sign}[d K / d c]=-\operatorname{sign}\left|\begin{array}{ccc}
0 & V_{K, L}^{\prime \prime} & 0 \\
-V_{L, c}^{\prime \prime} & V_{L, L}^{\prime \prime} & 0 \\
-V_{\phi, c}^{\prime \prime} & 0 & V_{\phi, \phi}^{\prime \prime}
\end{array}\right|=-\operatorname{sign}\left[V_{\phi, \phi}^{\prime \prime} V_{K, L}^{\prime \prime} V_{L, c}^{\prime \prime}\right]<0
$$

Applying similar methodology, we infer that part A of proposition 1 follows from (A5) and (A4).

Applying the first order conditions (A1), and the Cobb-Douglas output specification (1), it follows that the optimal capital and labor levels, denoted by $\widetilde{K}$ and $\widetilde{L}$, is

$$
\begin{gathered}
\widetilde{K}=\left\{[1-(1-\chi) b] \frac{A \alpha^{1-\beta}}{(1+\rho)^{1-\beta}} \frac{1}{[E(l c)]^{\beta}}\right\}^{1 /(1-\alpha-\beta)} \\
\tilde{L}=\tilde{K} \frac{\beta(1+\rho)}{\alpha E(l c)}
\end{gathered}
$$

Note that, applying the envelope theorem,

$$
\frac{d E(l c)}{d c}=\frac{\partial E(l c)}{\partial \phi} \frac{d \phi}{d c}+\frac{\partial E(l c)}{\partial c}=\int_{1-\bar{\varepsilon}}^{\phi}\left(\frac{b}{\chi}+a\right) \frac{1}{2 \bar{\varepsilon}} d \varepsilon+\int_{(1-\bar{\varepsilon}) \chi}^{1-\bar{\varepsilon}} \frac{b}{\chi 2 \bar{\varepsilon}} d \varepsilon>0 .
$$

Hence, higher enforcement costs would increase the expected cost of employing labor, reducing thereby the optimal investment, hence

$$
\frac{d \widetilde{K}}{d c}<0
$$

Similar analysis implies that $\frac{d \tilde{L}}{d c}<0$.

Note that Claim 2 then follows directly from equation (A.6).

\section{Proof of Claim 3}

By equation (A6) if follows that 
(A9)

$$
\frac{\widetilde{K}^{*}}{\widetilde{K}}=\left\{\frac{[E(l c)]}{\left[E\left(l c^{*}\right)\right]}\right\}^{\beta /(1-\alpha-\beta)}
$$

Hence, given that $c^{*}=\psi c$

$$
\frac{d \log \left(\frac{\tilde{K}^{*}}{\tilde{K}}\right)}{d c}=\frac{\beta}{1-\alpha-\beta}\left\{\frac{Q}{E(l c)}-\frac{\psi Q^{*}}{E\left(l c^{*}\right)}\right\}
$$

or

$$
\frac{d \log \left(\frac{\tilde{K}^{*}}{\tilde{K}}\right)}{d c}=\frac{\beta}{1-\alpha-\beta} \frac{1}{c}\left\{\frac{c Q}{E(l c)}-\frac{c^{*} Q^{*}}{E\left(l c^{*}\right)}\right\}
$$

Note that

$$
\frac{d\left[\frac{c Q}{E(l c)}\right]}{d c}=\frac{Q}{[E(l c)]^{2}}[E(l c)-c Q]>0 .
$$

Applying (A12) to (A11) we can infer that

$$
\frac{d \log \left(\frac{\tilde{K}^{*}}{\tilde{K}}\right)}{d c}<0
$$




\section{$\underline{\text { References }}$}

Aitken, Brian J., and Ann E. Harrison, (1999), " Do Domestic Firms Benefit from Direct Foreign Investment? Evidence from Venezuela " American Economic Review, June, 89(3), 605-618.

Barrell, Ray and Nigel Pain, (1997), "Foreign Direct Investment, Technological Change, and Economic Growth within Europe,” Economic Journal, 107, November, 1770-1786.

Blomström, Magnus, (1983), Foreign Investment and Spillovers, Routledge, London and New York.

Feenstra (2002, Chapter 11), Advanced International Trade: Theory and Evidence, forthcoming, Princeton University Press, 2003.

Fosfuri, Andrea, Massimo Motta, and Thomas Rønde, "Foreign Direct Investment and Spillovers Through Workers' Mobility, Journal of International Economics, 53, $205-$ 222.

Haddad, Mona, and Ann Harrison (1993), "Are There Positive Spillovers from Direct Foreign Investment?”, Journal of Development Economics, Vol. 42, pp. 51-74.

Hines, James R., (1995), "Forbidden Payment: Foreign Bribery and American Business After 1977,” NBER Working Paper no. 5266, September.

Lipsey, Robert E. (2002), "Home and Host Country Effects of FDI," manuscript, presented at The Challenges to Globalization, CEPR/NBER/SNS Conference, May.

Lipsey, Robert E. and Fredrik Sjöholm (2001), "Foreign Direct Investment and Wages in Indonesian Manufacturing," NBER Working Paper No. 8299, Cambridge, MA, National Bureau of Economic Research.

Mankiw, N. Gregory, Romer, David, and David N. Weil, (1992), "A Contribution to the Empirics of Economic Growth," Quarterly Journal of Economics, May, 107(2), 407437.

Markusen, James R. (2002), Multinational Firms and the Theory of International Trade, MIT Press.

Markusen, James R. (2001), "Contracts, Intellectual Property Rights, and Multinational Investment in Developing Countries," Journal of International Economics, 53, 189204.

Mauro, Paolo, (1995), “Corruption and Growth,” Quarterly Journal of Economics, August, 681-712. 
Okamoto, Yumiko, and Fredrick Sjöholm (1999), "FDI and the Dynamics of Productivity: Microeconomic Evidence," manuscript.

Razin, Assaf, Efraim Sadka, and Chi-Wa Yuen, (1999), "Excessive FDI Flows Under Asymmetric Information," NBER Working Paper no. 7400.

Smarzynska, Beata K. and Wei, Shang-Jin, (2000), Corruption and Composition of Foreign Direct Investment: Firm-Level Evidence, NBER Working Paper no. 7969, October.

Wei, Shang-Jin, (1997), "Why is Corruption So Much More Taxing than Tax? Arbitrariness Kills,” NBER Working Paper no. 6255, November.

(2000), "How Taxing is Corruption on International Investors?," Review of Economics and Statistics, 82(1), 1-11.

Wheeler, David, and Ashoka Mody (1992), "International Investment Location Decisions: The Case of U.S. Firms," Journal of International Economics, August, 33(1-2), 5776. 


\section{Table 1. Summary Statistics}

\section{Developing Nations}

\begin{tabular}{|c|c|c|c|c|c|}
\hline & Mean & Minimum & Maximum & $\begin{array}{c}\text { Standard } \\
\text { Deviation }\end{array}$ & $\begin{array}{c}\# \text { of } \\
\text { Countries }\end{array}$ \\
\hline InstEff $_{i}$ & 4.6684 & 0 & 8.3333 & 1.7595 & 76 \\
\hline$F D I / G F C F_{i}$ & 0.1049 & -0.0930 & 0.3811 & 0.0957 & 76 \\
\hline$F D I /$ PVT $_{i}$ & 0.1861 & -0.0019 & 0.7056 & 0.1613 & 42 \\
\hline${\text { Ores \& } \text { Metals }_{i}} 10.178$ & 0.03 & 61.18 & 16.0499 & 50 \\
\hline
\end{tabular}

\section{Developed Nations}

\begin{tabular}{|c|c|c|c|c|c|}
\hline & Mean & Minimum & Maximum & $\begin{array}{c}\text { Standard } \\
\text { Deviation }\end{array}$ & $\begin{array}{c}\# \text { of } \\
\text { Countries }\end{array}$ \\
\hline InstEff $_{i}$ & 8.8794 & 6.6667 & 10 & 1.0998 & 21 \\
\hline$F D I / G F C F_{i}$ & 0.1107 & 0.0021 & 0.3347 & 0.0900 & 21 \\
\hline$F D I /$ PVT $_{i}$ & 0.1262 & 0.0027 & 0.3833 & 0.1047 & 10 \\
\hline Ores \& Metals $_{i}$ & 4.8495 & 0.95 & 16.98 & 4.0513 & 21 \\
\hline
\end{tabular}

Note: Corrupt $_{i}$ is corruption index from Mauro (2000). Note that index is decreasing in domestic corruption level. $F D I / G F C F_{i}$ represents average ratio of inward foreign direct investment to gross fixed capital formation, while $F D I / P V T_{i}$ represents ratio of inward foreign direct investment to private domestic investment. Corrupt $t_{i}$ and Ores \& Metals $s_{i}$ values are for 1989. FDI / GFCF $F_{i}$ and FDI / PVT $T_{i}$ values are averages from 1990-1999. 
TABLE 2. Impact of Corruption on FDI/GFCF.

I. Full Sample

\section{$\underline{\text { Weighted }}$}

Unweighted

$\begin{array}{ccccc}\alpha & -0.029 & -0.052 & 0.071^{* *} & 0.030 \\ & (0.038) & (0.041) & (0.029) & (0.022) \\ \text { InstEff }_{i} & 0.023^{* *} & 0.022^{* *} & 0.007 & 0.014^{* *} \\ \text { Developed } & (0.007) & (0.008) & (0.005) & (0.005) \\ & -0.098^{* *} & -0.078^{* *} & -0.025 & -0.049 \\ {\text { Ores \& } \text { Metals }_{i}}^{(0.029)} & (0.029) & (0.030) & (0.033) \\ & & 0.004^{* *} & & 0.001^{*} \\ \text { \# of obs } & & (0.002) & & (0.001) \\ \text { R-squared } & 97 & 71 & & \\ & 0.15 & 0.22 & 0.02 & 0.09\end{array}$

II. Developed Nations

\section{Weighted}

\begin{tabular}{lcccc}
\multicolumn{1}{c}{$\alpha$} & $-0.207^{*}$ & -0.179 & -0.104 & -0.110 \\
\multicolumn{1}{c}{ InstEff $_{i}$} & $(0.108)$ & $(0.116)$ & $(0.130)$ & $(0.130)$ \\
& $0.032^{* *}$ & $0.026^{*}$ & 0.024 & $0.028^{*}$ \\
${\text { Ores \& } \text { Metals }_{i}}^{(0.013)}$ & $(0.015)$ & $(0.015)$ & $(0.015)$ \\
& & 0.007 & & -0.005 \\
\# of obs & & $(0.006)$ & & $(0.004)$ \\
R-squared & 21 & 21 & & \\
& 0.16 & 0.23 & 0.09 & 0.14
\end{tabular}

\section{Developing Nations}

\begin{tabular}{ccccc}
\multicolumn{2}{c}{ Weighted } & \multicolumn{2}{c}{ Unweighted } \\
$\alpha$ & 0.019 & 0.001 & $0.079^{* *}$ & 0.035 \\
\multirow{2}{*}{ InstEff $_{i}$} & $(0.024)$ & $(0.029)$ & $(0.031)$ & $(0.031)$ \\
& $0.013^{* *}$ & $0.014^{* *}$ & 0.006 & $0.013^{* *}$ \\
Ores \& Metals $_{i}$ & $(0.004)$ & $(0.005)$ & $(0.006)$ & $(0.005)$ \\
& & $0.002^{* *}$ & & $0.001^{*}$ \\
\# of obs & & $(0.001)$ & & $(0.001)$ \\
R-squared & 76 & 50 & 76 & 50 \\
& 0.13 & 0.25 & 0.01 & 0.11
\end{tabular}

Note: Estimation by ordinary least squares. White's heteroskedasticity-adjusted standard errors in parentheses.

** indicates significance at a 5 percent confidence level. * indicates significance at a ten percent level. 
TABLE 3. Impact of Corruption on FDI/PVT.

I. Full Sample

\begin{tabular}{ccccc} 
& Weighted & \multicolumn{3}{c}{ Unweighted } \\
\cline { 2 - 4 }$\alpha$ & -0.004 & -0.017 & $0.152^{*}$ & $0.077^{* *}$ \\
\multirow{2}{*}{ InstEff $_{i}$} & $(0.054)$ & $(0.058)$ & $(0.077)$ & $(0.036)$ \\
& $0.028^{* *}$ & $0.025^{*}$ & 0.008 & $0.014^{*}$ \\
Developed & $(0.012)$ & $(0.014)$ & $(0.013)$ & $(0.008)$ \\
& $-0.180^{* *}$ & $-0.157^{*}$ & -0.094 & -0.098 \\
Ores \& Metals & $(0.078)$ & $(0.087)$ & $(0.063)$ & $(0.060)$ \\
& & $0.003^{*}$ & & 0.003 \\
\# of obs & & $(0.002)$ & & $(0.002)$ \\
R-squared & & & & \\
& 52 & 43 & 52 & 43 \\
& 0.26 & 0.31 & 0.03 & 0.18
\end{tabular}

II. Developing Nations

Weighted

$$
\begin{gathered}
\alpha \\
\text { InstEff }_{i}
\end{gathered}
$$

Ores \& Metals $_{i}$

$$
\text { \# of obs }
$$$$
\text { R-squared }
$$

$$
\begin{gathered}
0.003 \\
(0.056) \\
0.026^{* *} \\
(0.013)
\end{gathered}
$$$$
-0.008
$$$$
(0.067)
$$$$
0.026
$$$$
(0.016)
$$$$
0.002
$$$$
\text { (0.002) }
$$

\section{Unweighted}

$$
\begin{array}{cc}
0.147^{*} & 0.066^{*} \\
(0.078) & (0.035) \\
0.009 & 0.016^{*} \\
(0.014) & (0.008)
\end{array}
$$

33

0.21

Note: Estimation by ordinary least squares. White's heteroskedasticity-adjusted standard errors in parentheses. ** indicates significance at a 5 percent confidence interval. * indicates significance at a ten percent confidence level. 


\section{Table 4. Impact of Corruption on FDI/GFCF (Conditioning Variables Included).}

With Ores and Metals

\begin{tabular}{|c|c|c|c|c|c|c|c|c|c|}
\hline Constant & $\begin{array}{l}-1.871 * * \\
(0.725) \\
\end{array}$ & $\begin{array}{l}-1.269^{*} \\
(0.710) \\
\end{array}$ & $\begin{array}{l}-0.052 \\
(0.042) \\
\end{array}$ & $\begin{array}{l}-0.061 \\
(0.048) \\
\end{array}$ & $\begin{array}{l}-0.058 \\
(0.043) \\
\end{array}$ & $\begin{array}{l}-0.088^{*} \\
(0.051) \\
\end{array}$ & $\begin{array}{l}-0.884 \\
(0.572) \\
\end{array}$ & $\begin{array}{l}-0.074^{*} \\
(0.042) \\
\end{array}$ & $\begin{array}{l}-0.046 \\
(0.045) \\
\end{array}$ \\
\hline Corruption & $\begin{array}{l}0.013 \\
(0.009)\end{array}$ & $\begin{array}{l}0.019 * * \\
(0.009)\end{array}$ & $\begin{array}{l}0.021 * * \\
(0.007)\end{array}$ & $\begin{array}{l}0.022 * * \\
(0.008)\end{array}$ & $\begin{array}{l}0.022 * * \\
(0.007)\end{array}$ & $\begin{array}{l}0.023 * * \\
(0.007)\end{array}$ & $\begin{array}{l}0.017 * * \\
(0.008)\end{array}$ & $\begin{array}{l}0.021 * * \\
(0.007)\end{array}$ & $\begin{array}{l}0.022 * * \\
(0.007)\end{array}$ \\
\hline Developed & $\begin{array}{l}-0.124^{*} \\
(0.063)\end{array}$ & $\begin{array}{l}-0.122^{*} \\
(0.066)\end{array}$ & $\begin{array}{l}-0.068 * * \\
(0.031)\end{array}$ & $\begin{array}{l}-0.084 \\
(0.052)\end{array}$ & $\begin{array}{l}-0.071 * * \\
(0.031)\end{array}$ & $\begin{array}{l}-0.048 \\
(0.035)\end{array}$ & $\begin{array}{l}-0.119 * * \\
(0.046)\end{array}$ & $\begin{array}{l}-0.066^{* *} \\
(0.033)\end{array}$ & $\begin{array}{l}-0.079^{* *} \\
(0.035)\end{array}$ \\
\hline Ores and Metals & $\begin{array}{l}0.003 \\
(0.002)\end{array}$ & $\begin{array}{l}0.004 * * \\
(0.002)\end{array}$ & $\begin{array}{l}0.004^{* *} \\
(0.002)\end{array}$ & $\begin{array}{l}0.004 * * \\
(0.002)\end{array}$ & $\begin{array}{l}0.004 * * \\
(0.002)\end{array}$ & $\begin{array}{l}0.003 * * \\
(0.002)\end{array}$ & $\begin{array}{l}0.004 * * \\
(0.002)\end{array}$ & $\begin{array}{l}0.003^{*} \\
(0.002)\end{array}$ & $\begin{array}{l}0.004 * * \\
(0.002)\end{array}$ \\
\hline $\begin{array}{l}\text { Sub-Saharan } \\
\text { Africa }\end{array}$ & $\begin{array}{l}-0.022 \\
(0.172)\end{array}$ & $\begin{array}{l}-0.061 \\
(0.181) \\
\end{array}$ & $\begin{array}{l}0.007 \\
(0.151)\end{array}$ & & & & & & \\
\hline Openness & $\begin{array}{l}-0.006 \\
(0.056)\end{array}$ & $\begin{array}{l}-0.034 \\
(0.058)\end{array}$ & & $\begin{array}{l}0.019 \\
(0.049)\end{array}$ & & & & & \\
\hline Access & $\begin{array}{l}-0.020 \\
(0.044)\end{array}$ & $\begin{array}{l}-0.026 \\
(0.047)\end{array}$ & & & $\begin{array}{l}-0.027 \\
(0.044) \\
\end{array}$ & & & & \\
\hline Tropics & $\begin{array}{l}0.075 \\
(0.053)\end{array}$ & $\begin{array}{l}0.064 \\
(0.053)\end{array}$ & & & & $\begin{array}{l}0.062 \\
(0.049)\end{array}$ & & & \\
\hline Life & $\begin{array}{l}0.454 * * \\
(0.190) \\
\end{array}$ & $\begin{array}{l}0.313 \\
(0.188) \\
\end{array}$ & & & & & $\begin{array}{l}0.216 \\
(0.148)\end{array}$ & & \\
\hline $\begin{array}{l}\text { Ethno-linguistic } \\
\text { Fractionalization }\end{array}$ & $\begin{array}{l}0.001 * * \\
(0.000)\end{array}$ & & & & & & & $\begin{array}{l}0.001^{* *} \\
(0.000)\end{array}$ & \\
\hline Inflation & $\begin{array}{l}-0.000 \\
(0.001) \\
\end{array}$ & $\begin{array}{l}-0.001 \\
(0.001)\end{array}$ & & & & & & & $\begin{array}{l}-0.001 \\
(0.001)\end{array}$ \\
\hline \# of obs & 60 & 61 & 67 & 64 & 67 & 66 & 66 & 66 & 63 \\
\hline R-squared & 0.38 & 0.29 & 0.21 & 0.21 & 0.21 & 0.23 & 0.24 & 0.27 & 0.22 \\
\hline
\end{tabular}

Without Ores and Metals

\begin{tabular}{|c|c|c|c|c|c|c|c|c|c|}
\hline Constant & $\begin{array}{l}-1.820^{* *} \\
(0.651)\end{array}$ & $\begin{array}{l}-1.140^{*} \\
(0.651)\end{array}$ & $\begin{array}{l}-0.032 \\
(0.037)\end{array}$ & $\begin{array}{l}-0.033 \\
(0.041) \\
\end{array}$ & $\begin{array}{l}-0.035 \\
(0.037) \\
\end{array}$ & $\begin{array}{l}-0.078^{*} \\
(0.044) \\
\end{array}$ & $\begin{array}{l}-0.842 * \\
(0.492)\end{array}$ & $\begin{array}{l}-0.064^{*} \\
(0.037)\end{array}$ & $\begin{array}{l}-0.032 \\
(0.040)\end{array}$ \\
\hline Corruption & $\begin{array}{l}0.014^{*} \\
(0.008)\end{array}$ & $\begin{array}{l}0.019 * * \\
(0.008)\end{array}$ & $\begin{array}{l}0.022 * * \\
(0.006)\end{array}$ & $\begin{array}{l}0.022^{* *} \\
(0.007)\end{array}$ & $\begin{array}{l}0.023 * * \\
(0.007)\end{array}$ & $\begin{array}{l}0.024 * * \\
(0.006)\end{array}$ & $\begin{array}{l}0.018 * * \\
(0.007)\end{array}$ & $\begin{array}{l}0.023 * * \\
(0.006)\end{array}$ & $\begin{array}{l}0.022 * * \\
(0.007)\end{array}$ \\
\hline Developed & $\begin{array}{l}-0.119^{* *} \\
(0.057) \\
\end{array}$ & $\begin{array}{l}-0.110^{*} \\
(0.061) \\
\end{array}$ & $\begin{array}{l}-0.087 * * \\
(0.027) \\
\end{array}$ & $\begin{array}{l}-0.093 * * \\
(0.046) \\
\end{array}$ & $\begin{array}{l}-0.091 * * \\
(0.027) \\
\end{array}$ & $\begin{array}{l}-0.058^{*} \\
(0.030) \\
\end{array}$ & $\begin{array}{l}-0.137 * * \\
(0.040) \\
\end{array}$ & $\begin{array}{l}-0.085^{* *} \\
(0.027) \\
\end{array}$ & $\begin{array}{l}-0.085^{* *} \\
(0.033) \\
\end{array}$ \\
\hline $\begin{array}{l}\text { Sub-Saharan } \\
\text { Africa }\end{array}$ & $\begin{array}{l}0.054 \\
(0.100)\end{array}$ & $\begin{array}{l}0.024 \\
(0.106)\end{array}$ & $\begin{array}{l}0.034 \\
(0.085)\end{array}$ & & & & & & \\
\hline Openness & $\begin{array}{l}-0.005 \\
(0.051)\end{array}$ & $\begin{array}{l}-0.036 \\
(0.053)\end{array}$ & & $\begin{array}{l}0.006 \\
(0.044)\end{array}$ & & & & & \\
\hline Access & $\begin{array}{l}-0.019 \\
(0.040)\end{array}$ & $\begin{array}{l}-0.023 \\
(0.043)\end{array}$ & & & $\begin{array}{l}-0.024 \\
(0.040)\end{array}$ & & & & \\
\hline Tropics & $\begin{array}{l}0.083^{*} \\
(0.048)\end{array}$ & $\begin{array}{l}0.078 \\
(0.048)\end{array}$ & & & & $\begin{array}{l}0.080^{*} \\
(0.042)\end{array}$ & & & \\
\hline Life & $\begin{array}{l}0.440 * * \\
(0.170)\end{array}$ & $\begin{array}{l}0.281 \\
(0.172)\end{array}$ & & & & & $\begin{array}{l}0.211 \\
(0.128)\end{array}$ & & \\
\hline $\begin{array}{l}\text { Ethno-linguistic } \\
\text { Fractionalization }\end{array}$ & $\begin{array}{l}0.001^{* *} \\
(0.000)\end{array}$ & & & & & & & $\begin{array}{l}0.001 * * \\
(0.000)\end{array}$ & \\
\hline Inflation & $\begin{array}{l}0.000 \\
(0.001)\end{array}$ & $\begin{array}{l}-0.001 \\
(0.001)\end{array}$ & & & & & & & $\begin{array}{l}0.000 \\
(0.001)\end{array}$ \\
\hline \# of obs & 74 & 76 & 87 & 84 & 87 & 86 & 85 & 85 & 79 \\
\hline R-squared & 0.34 & 0.21 & 0.14 & 0.14 & 0.14 & 0.17 & 0.16 & 0.21 & 0.14 \\
\hline
\end{tabular}

Note: Estimation by weighted least squares, with weights by GDP. White's heteroskedasticity-adjusted standard errors in parentheses. See text for conditioning variable definitions. ** indicates significance at a 5 percent confidence interval. * indicates significance at a ten percent confidence level. 


\section{Table 5. Impact of Corruption on FDI/PVT (Conditioning Variables Included).}

\begin{tabular}{|c|c|c|c|c|c|c|c|c|c|}
\hline Constant & $\begin{array}{l}-3.117 * * \\
(0.979) \\
\end{array}$ & $\begin{array}{l}-0.762 \\
(1.077)\end{array}$ & $\begin{array}{l}-0.023 \\
(0.071)\end{array}$ & $\begin{array}{l}-0.006 \\
(0.081)\end{array}$ & $\begin{array}{l}-0.026 \\
(0.072)\end{array}$ & $\begin{array}{l}-0.048 \\
(0.086)\end{array}$ & $\begin{array}{l}0.128 \\
(0.923)\end{array}$ & $\begin{array}{l}-0.032 \\
(0.064)\end{array}$ & $\begin{array}{l}-0.016 \\
(0.069) \\
\end{array}$ \\
\hline Corruption & $\begin{array}{l}-0.011 \\
(0.015)\end{array}$ & $\begin{array}{l}0.028^{*} \\
(0.016)\end{array}$ & $\begin{array}{l}0.025^{*} \\
(0.013)\end{array}$ & $\begin{array}{l}0.024^{*} \\
(0.014)\end{array}$ & $\begin{array}{l}0.026^{*} \\
(0.013)\end{array}$ & $\begin{array}{l}0.027^{*} \\
(0.014)\end{array}$ & $\begin{array}{l}0.026^{*} \\
(0.014)\end{array}$ & $\begin{array}{l}0.015 \\
(0.012)\end{array}$ & $\begin{array}{l}0.030^{* *} \\
(0.013)\end{array}$ \\
\hline Developed & $\begin{array}{l}-0.130 \\
(0.083)\end{array}$ & $\begin{array}{l}-0.173 \\
(0.105)\end{array}$ & $\begin{array}{l}-0.150 * * \\
(0.055) \\
\end{array}$ & $\begin{array}{l}-0.120 \\
(0.086)\end{array}$ & $\begin{array}{l}-0.151 * * \\
(0.055) \\
\end{array}$ & $\begin{array}{l}-0.141 * * \\
(0.058) \\
\end{array}$ & $\begin{array}{l}-0.141^{*} \\
(0.079)\end{array}$ & $\begin{array}{l}-0.070 \\
(0.054)\end{array}$ & $\begin{array}{l}-0.196^{* *} \\
(0.061) \\
\end{array}$ \\
\hline Ores and Metals & $\begin{array}{l}0.002 \\
(0.002)\end{array}$ & $\begin{array}{l}0.005^{*} \\
(0.003) \\
\end{array}$ & $\begin{array}{l}0.003 \\
(0.002) \\
\end{array}$ & $\begin{array}{l}0.003 \\
(0.002)\end{array}$ & $\begin{array}{l}0.004 \\
(0.002) \\
\end{array}$ & $\begin{array}{l}0.003 \\
(0.002) \\
\end{array}$ & $\begin{array}{l}0.004 \\
(0.002)\end{array}$ & $\begin{array}{l}0.004 * \\
(0.002)\end{array}$ & $\begin{array}{l}0.005^{* *} \\
(0.002) \\
\end{array}$ \\
\hline $\begin{array}{l}\text { Sub-Saharan } \\
\text { Africa }\end{array}$ & $\begin{array}{l}0.046 \\
(0.298)\end{array}$ & $\begin{array}{l}-0.123 \\
(0.379)\end{array}$ & $\begin{array}{l}-0.069 \\
(0.371)\end{array}$ & & & & & & \\
\hline Openness & $\begin{array}{l}-0.023 \\
(0.065)\end{array}$ & $\begin{array}{l}-0.084 \\
(0.082)\end{array}$ & & $\begin{array}{l}-0.032 \\
(0.072)\end{array}$ & & & & & \\
\hline Access & $\begin{array}{l}0.029 \\
(0.073)\end{array}$ & $\begin{array}{l}-0.030 \\
(0.092)\end{array}$ & & & $\begin{array}{l}-0.024 \\
(0.090)\end{array}$ & & & & \\
\hline Tropics & $\begin{array}{l}0.074 \\
(0.062) \\
\end{array}$ & $\begin{array}{l}0.061 \\
(0.074)\end{array}$ & & & & $\begin{array}{l}0.037 \\
(0.072) \\
\end{array}$ & & & \\
\hline Life & $\begin{array}{l}0.797 * * \\
(0.257) \\
\end{array}$ & $\begin{array}{l}0.196 \\
(0.286) \\
\end{array}$ & & & & & $\begin{array}{l}-0.039 \\
(0.240)\end{array}$ & & \\
\hline $\begin{array}{l}\text { Ethno-linguistic } \\
\text { Fractionalization }\end{array}$ & $\begin{array}{l}0.001 * * \\
(0.001)\end{array}$ & & & & & & & $\begin{array}{l}0.001 * * \\
(0.000)\end{array}$ & \\
\hline Inflation & $\begin{array}{l}0.000 \\
(0.001)\end{array}$ & $\begin{array}{l}-0.002^{*} \\
(0.001)\end{array}$ & & & & & & & $\begin{array}{l}-0.002 \\
(0.001)\end{array}$ \\
\hline \# of obs & 40 & 41 & 41 & 41 & 41 & 41 & 41 & 40 & 41 \\
\hline R-squared & 0.53 & 0.38 & 0.29 & 0.30 & 0.29 & 0.30 & 0.29 & 0.33 & 0.34 \\
\hline
\end{tabular}

Without Ores and Metals

\begin{tabular}{|c|c|c|c|c|c|c|c|c|c|}
\hline Constant & $\begin{array}{l}-3.235^{* *} \\
(0.919)\end{array}$ & $\begin{array}{l}-0.721 \\
(1.043)\end{array}$ & $\begin{array}{l}-0.011 \\
(0.065)\end{array}$ & $\begin{array}{l}0.007 \\
(0.072)\end{array}$ & $\begin{array}{l}-0.013 \\
(0.066)\end{array}$ & $\begin{array}{l}-0.053 \\
(0.076)\end{array}$ & $\begin{array}{l}-0.182 \\
(0.849)\end{array}$ & $\begin{array}{l}-0.034 \\
(0.063)\end{array}$ & $\begin{array}{l}-0.002 \\
(0.065)\end{array}$ \\
\hline Corruption & $\begin{array}{l}-0.011 \\
(0.014)\end{array}$ & $\begin{array}{l}0.029^{*} \\
(0.015)\end{array}$ & $\begin{array}{l}0.028^{* *} \\
(0.012)\end{array}$ & $\begin{array}{l}0.026^{* *} \\
(0.012)\end{array}$ & $\begin{array}{l}0.028^{* *} \\
(0.012)\end{array}$ & $\begin{array}{l}0.030 * * \\
(0.012)\end{array}$ & $\begin{array}{l}0.027 * * \\
(0.013)\end{array}$ & $\begin{array}{l}0.020^{*} \\
(0.011)\end{array}$ & $\begin{array}{l}0.031 * * \\
(0.012)\end{array}$ \\
\hline Developed & $\begin{array}{l}-0.130 \\
(0.078)\end{array}$ & $\begin{array}{l}-0.169 \\
(0.101)\end{array}$ & $\begin{array}{l}-0.173 * * \\
(0.049)\end{array}$ & $\begin{array}{l}-0.138^{*} \\
(0.080)\end{array}$ & $\begin{array}{l}-0.174^{* *} \\
(0.050)\end{array}$ & $\begin{array}{l}-0.153 * * \\
(0.053)\end{array}$ & $\begin{array}{l}-0.183 * * \\
(0.070)\end{array}$ & $\begin{array}{l}-0.102 * * \\
(0.049)\end{array}$ & $\begin{array}{l}-0.201^{* *} \\
(0.059)\end{array}$ \\
\hline $\begin{array}{l}\text { Sub-Saharan } \\
\text { Africa }\end{array}$ & $\begin{array}{l}0.117 \\
(0.217)\end{array}$ & $\begin{array}{l}-0.069 \\
(0.281)\end{array}$ & $\begin{array}{l}-0.016 \\
(0.266)\end{array}$ & & & & & & \\
\hline Openness & $\begin{array}{l}-0.024 \\
(0.062)\end{array}$ & $\begin{array}{l}-0.086 \\
(0.078) \\
\end{array}$ & & $\begin{array}{l}-0.037 \\
(0.067)\end{array}$ & & & & & \\
\hline Access & $\begin{array}{l}0.034 \\
(0.069)\end{array}$ & $\begin{array}{l}-0.023 \\
(0.090)\end{array}$ & & & $\begin{array}{l}-0.021 \\
(0.086)\end{array}$ & & & & \\
\hline Tropics & $\begin{array}{l}0.077 \\
(0.058)\end{array}$ & $\begin{array}{l}0.077 \\
(0.070)\end{array}$ & & & & $\begin{array}{l}0.065 \\
(0.064)\end{array}$ & & & \\
\hline Life & $\begin{array}{l}0.827 * * \\
(0.242)\end{array}$ & $\begin{array}{l}0.186 \\
(0.277)\end{array}$ & & & & & $\begin{array}{l}0.045 \\
(0.221)\end{array}$ & & \\
\hline $\begin{array}{l}\text { Ethno-linguistic } \\
\text { Fractionalization }\end{array}$ & $\begin{array}{l}0.002^{* *} \\
(0.000)\end{array}$ & & & & & & & $\begin{array}{l}0.001 * * \\
(0.000)\end{array}$ & \\
\hline Inflation & $\begin{array}{l}0.001 \\
(0.001)\end{array}$ & $\begin{array}{l}-0.001 \\
(0.001)\end{array}$ & & & & & & & $\begin{array}{l}-0.001 \\
(0.001)\end{array}$ \\
\hline \# of obs & 44 & 46 & 47 & 47 & 47 & 47 & 47 & 45 & 46 \\
\hline R-squared & 0.51 & 0.31 & 0.24 & 0.24 & 0.24 & 0.26 & 0.24 & 0.25 & 0.25 \\
\hline
\end{tabular}

Note: Estimation by weighted least squares, with weights by GDP. White's heteroskedasticity-adjusted standard errors in parentheses. See text for conditioning variable definitions. $* *$ indicates significance at a 5 percent confidence interval. * indicates significance at a ten percent confidence level. 


\section{Figure 1. Investment Flows and Institutional Efficiency.}

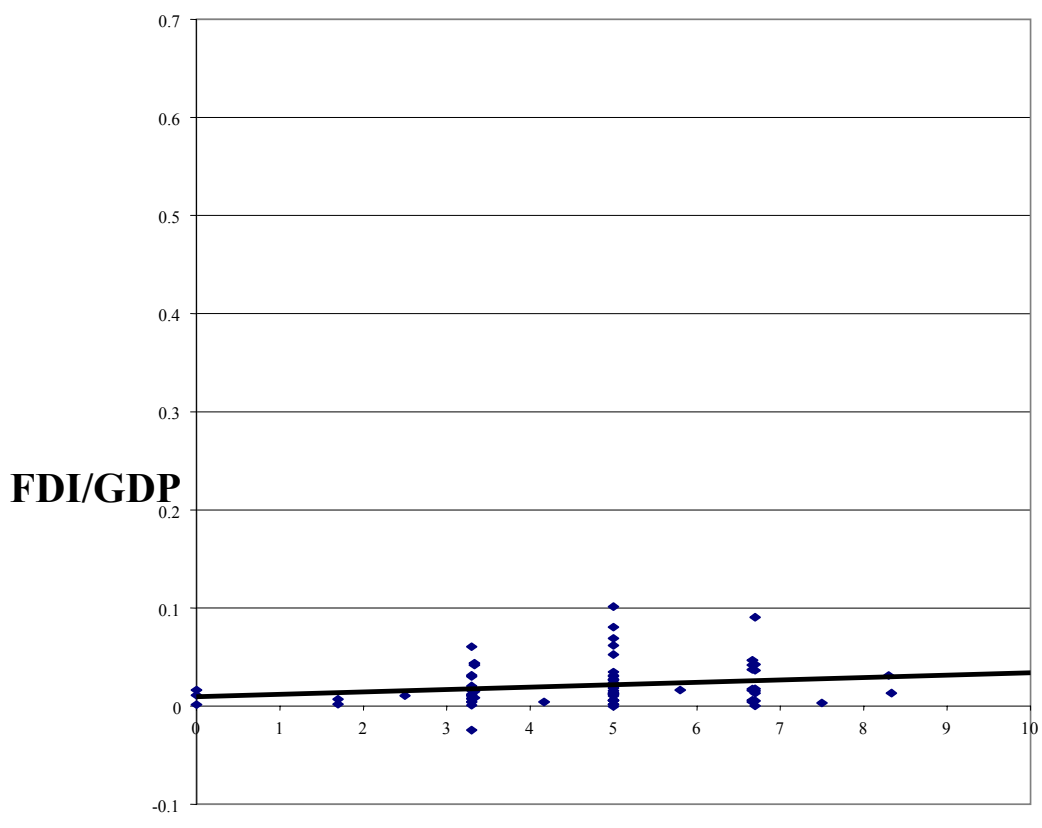

INST. EFFICIENCY

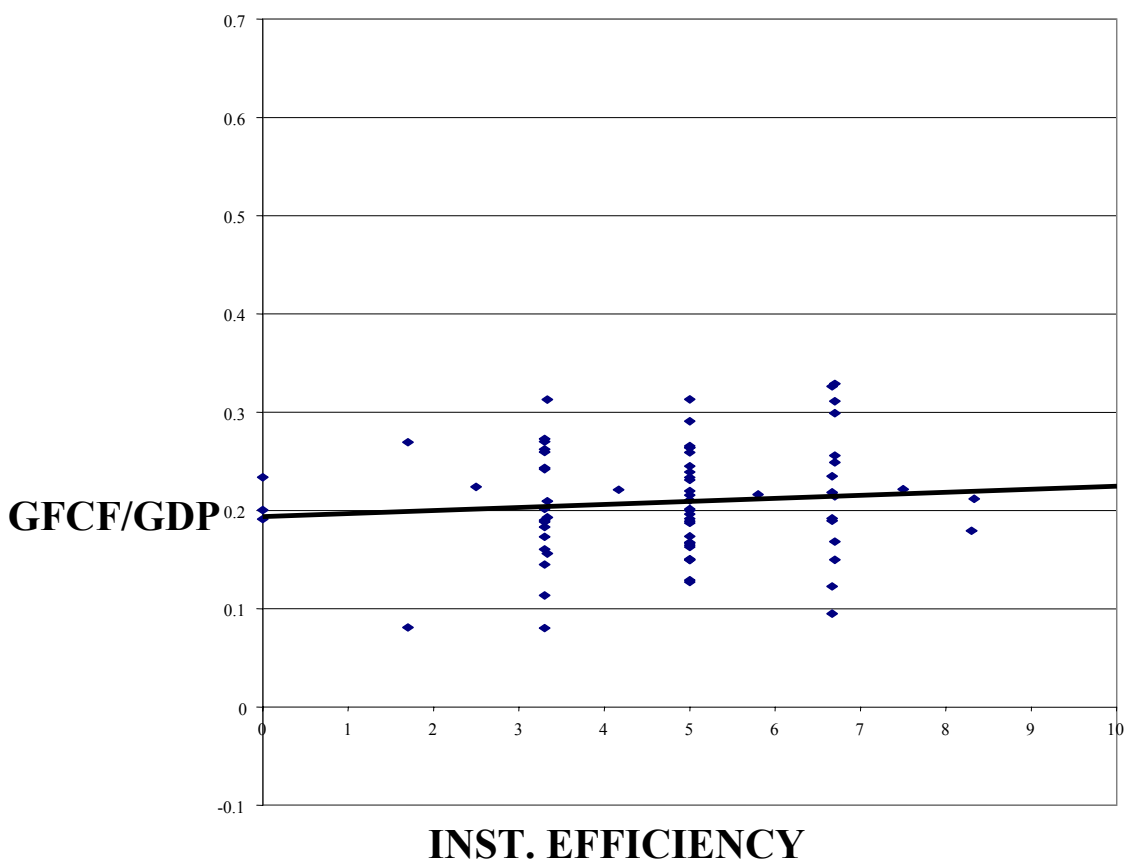

Note: Developing country sample. Institutional efficiency index based on a scale of 1 to 10 , with 10 representing lowest level of institutional efficiency. Investment data are averages of flows from 1990-1999. GFCF represents gross fixed capital formation. 


\section{Figure 2. FDI Ratios and Institutional Efficiency.}

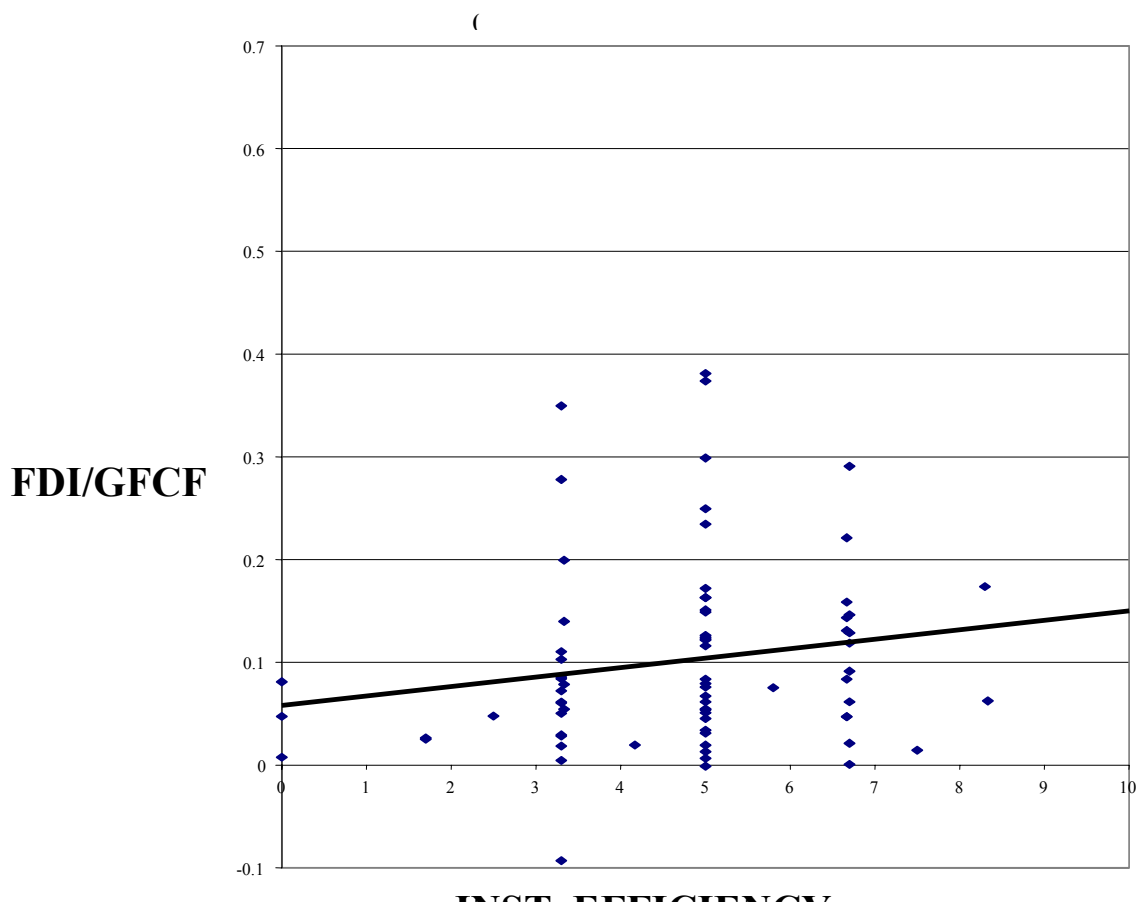

INST. EFFICIENCY

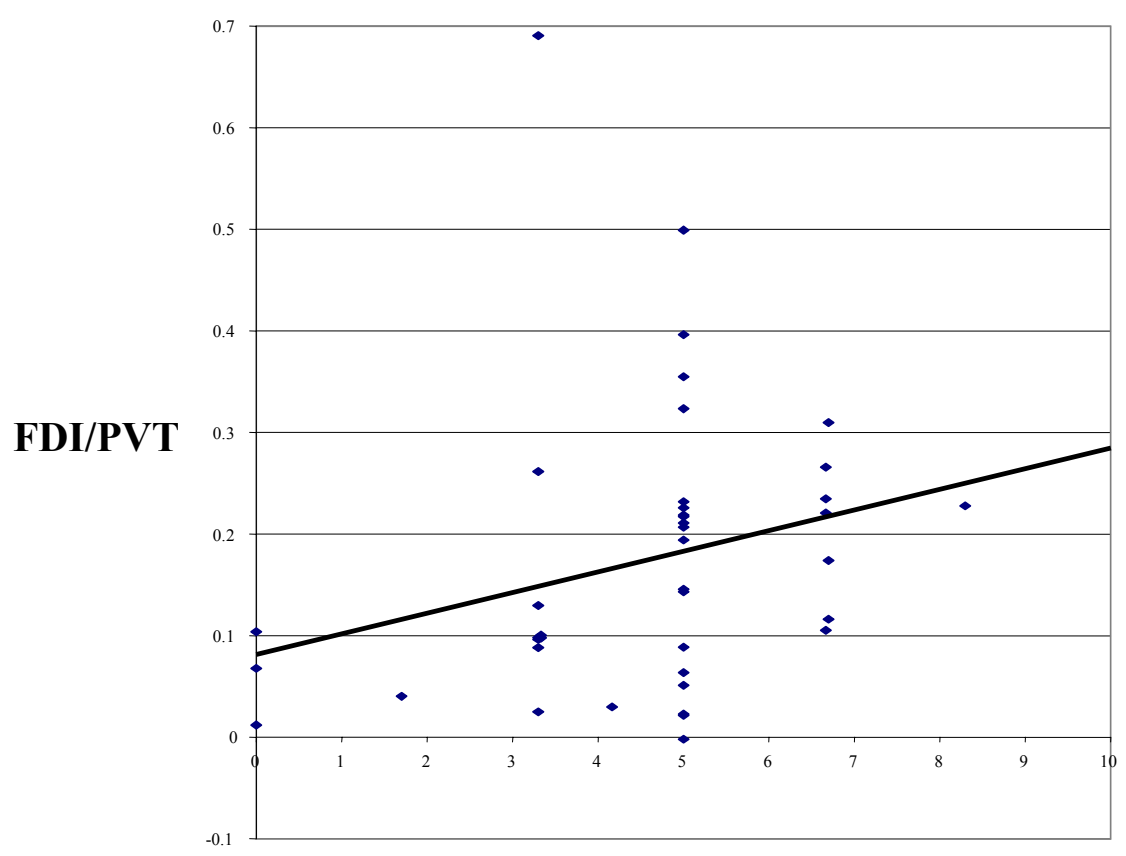

INST. EFFICIENCY

Note: Developing country sample. Institutional efficiency index based on a scale of 1 to 10 , with 10 representing lowest level of institutional efficiency. Investment data are averages of flows from 1990-1999. GFCF represents gross fixed capital formation. PVT represents private investment flows. See text for details. 